\title{
Distribution and feeding of epibenthic holothuroids on the reef flat of Laing Island (Papua New Guinea)*
}

\author{
Claude Massin ${ }^{1} \&$ Chris Doumen ${ }^{2}$ \\ ' Département des Invertébrés récents, Institut Royal des Sciences Naturelles de Belgique, Rue Vautier 29 - 1040 Bruxelles, \\ Belgium \\ ${ }^{2}$ Laboratorium voor Biochemie en Algemene Dierkunde, Rijksuniversitair Centrum Antwerpen, Groenenborgerlaan 171 - \\ 2020 Antwerpen, Belgium
}

\begin{abstract}
Among the 7 most abundant species of holothuroids found on the east reet flat of Laing Island (Papua New Guinea), Holothuria atra and Holothuria leucospilota represented more than $90 \%$ of the total number of individuals observed. Hydrodynamics was the most important factor regulating the distribution of the species studied. Ripple-marks and reduced sand were factors restricting holothuroid distribution. No relation was found between body size of the epibenthic holothuroids and particle-size classes of the gut sediment. Tentacular structures were not related to the size of particles ingested. Some holothuroids seem to physically select ingested sediment, while others do not. The behaviour of the population of one species is affected by the habitat and by the presence of other species. The partitioning of ingested sediment allows ecologically similar species to coexist.
\end{abstract}

\section{INTRODUCTION}

Holothuroids are dominant deposit-feeders on tropical coral reefs (Bakus 1973). Their abundance on tropical, sheltered shallow-water sediments raised questions about the adaptive strategies of co-existing species according to the degree of competitive interaction. Kohn (1971) hypothesized that deposit-feeders are more likely to be specialized to microhabitats than to food type. This was supported by studies of Rowe \& Doty (1977), Sloan (1979) and Lawrence (1980) on tropical epibenthic holothuroid populations who concluded that resource partitioning is largely on the basis of macro- and microhabitat preferences. If habitats do overlap, food partitioning and selective feeding could become important factors reducing competitive pressure (Roberts \& Bryce 1982). However, as stated by Lawrence (1980), observations on a large variety of species and localities are still lacking to make generalizations.

The purpose of this paper is to describe the numbers,

\footnotetext{
- Léopold III Biological Station of Laing Island, Papua New Guinea, Contribution No. 73
}

distribution, habitat selection and gut contents of the most common epibenthic deposit-feeding holothuroids of the reef flat of Laing Island, Papua New Guinea.

\section{MATERIALS AND METHODS}

Laing Island $\left(4^{\circ} 10^{\prime} 30^{\prime \prime} \mathrm{S}, 144^{\circ} 52^{\prime} 42^{\prime \prime} E_{i}\right.$ Fig. 1a \& 2) is located in Hansa bay (Madang Province) on the north coast of Papua New Guinea. The main morphological features of the reef flat are labelled according to the nomenclature of Battistini et al. (1975).

The bulk of the observations were made during July and August 1982. Some results were verified during October and November 1983 and September 1985. The study area was located on the east reef flat of Laing Island (Fig. 1c) where 4 large pools occur at low tide (labelled 1 to 4 in Fig. 1a \& 2). For a detailed description of the reef flat see Claereboudt et al. (in press).

Numbers of the holothuroids (epibenthic and semicryptic) were counted in eleven $40 \times 40 \mathrm{~m}$ quadrats. Nine quadrats were adjacent to each other along the beach side of the eastern reef ( $A$ to $I_{;}$Fig. 3 ). Two quadrats were on the north and south points of the 
island ( $\mathrm{J}$ and $\mathrm{K} ; \mathrm{Fig} .3$ ). Each quadrat was divided into 8 zones, $40 \times 5 \mathrm{~m}$ (e.g. A1, ..., A8), starting with Zone 1 adjoining the beach (Fig. 4). Within each zone, a $1 \mathrm{~m}^{2}$ wooden frame was placed every other meter while progressing in a zigzag pattern until at least 18 points had been processed (Fig. 4). All epibenthic holothuroids were counted in the $1 \mathrm{~m}^{2}$ quadrats. For less abundant species, the numbers of individuals in the entire zone $(40 \times 5 \mathrm{~m})$ were counted. Body lengths of the undisturbed individuals were measured with a ruler. Wet body weights were measured in the laboratory after individuals had been blotted dry for 5 min on tissue paper.

For analysis of ingested sediment, guts were dissec-
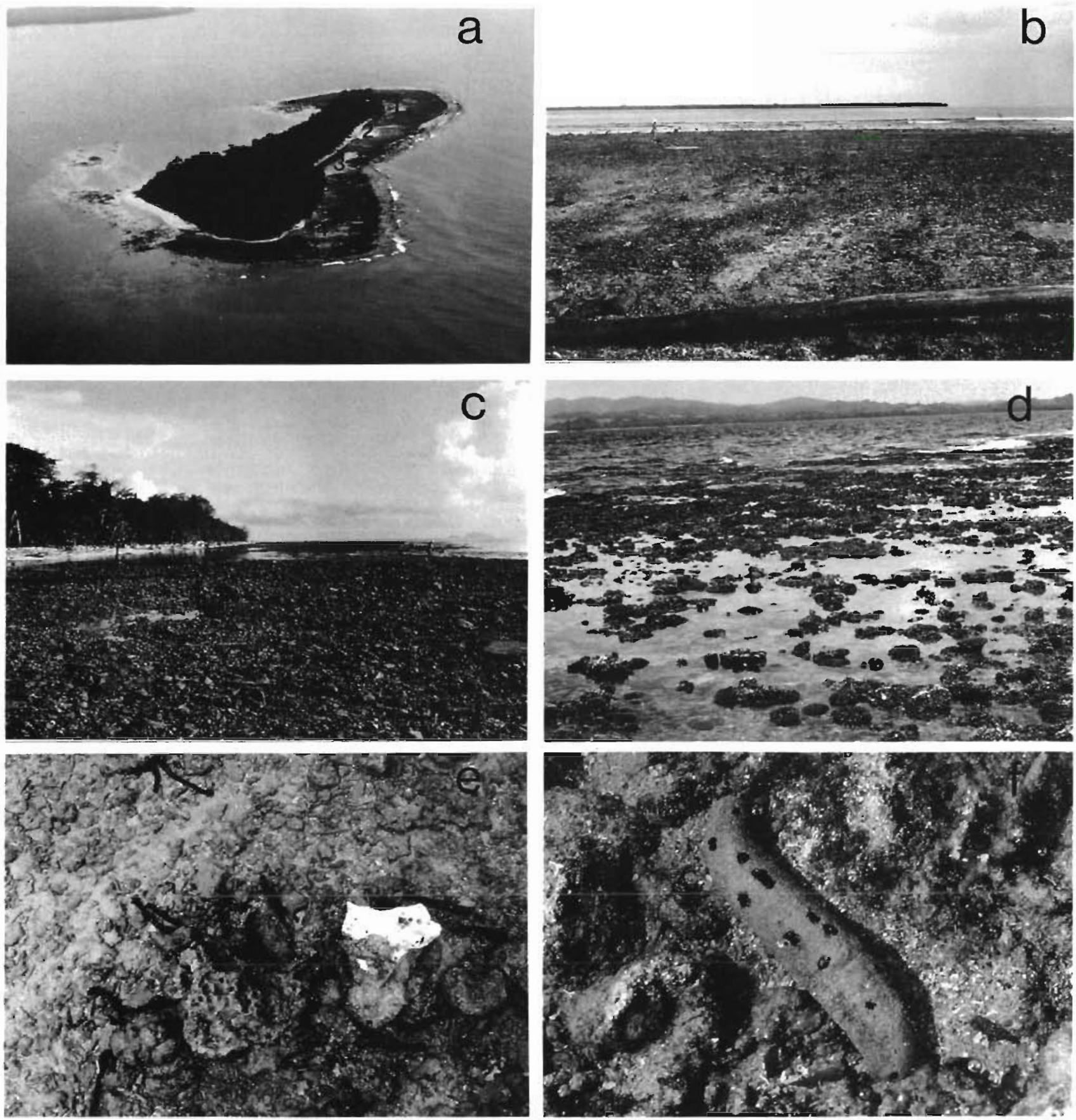

Fig. 1. (a) General view of Laing Island. 1 to 4 : location of pools on the east flat. (b) North reef flat, a large flat slab of dead coral without pools or large stones. (c) General view of the exst reef flat. The pool visible is Pool 3. Foreground is a rubble reef flat. (d) Edge of the reef flat with living colonies of coral. (e) Stones with clusters of Holothuria leucospilota (Pool 1). (f) Close-up of Holothuria atra 


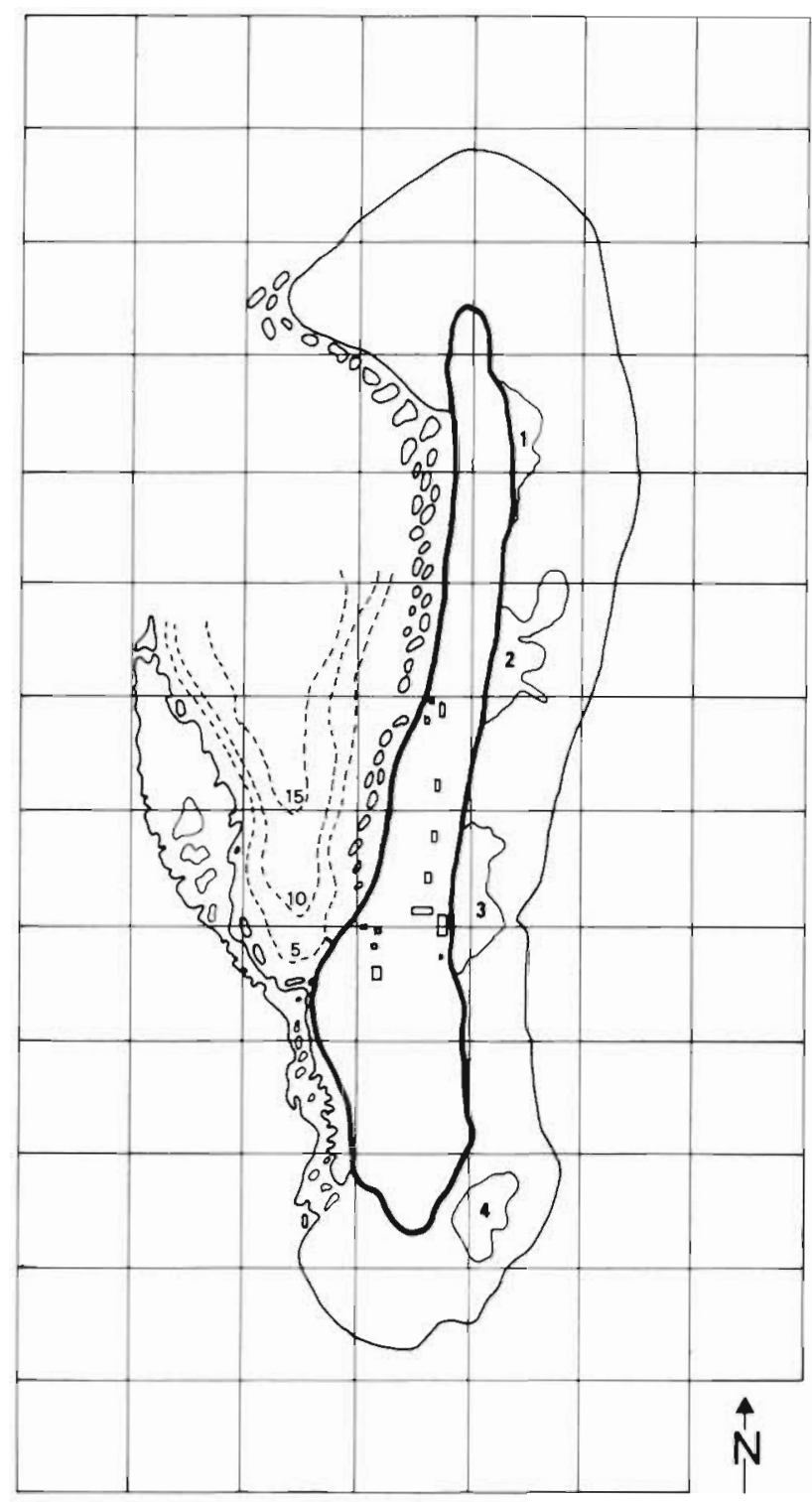

Loing Island (e.l.w.)

$200 \mathrm{~m}$

Fig. 2. Map of Laing Island at extreme low tide (e.l.w.). 1 to 4 indicate the 4 main pools. Boid line marks the part of the island which is never submerged

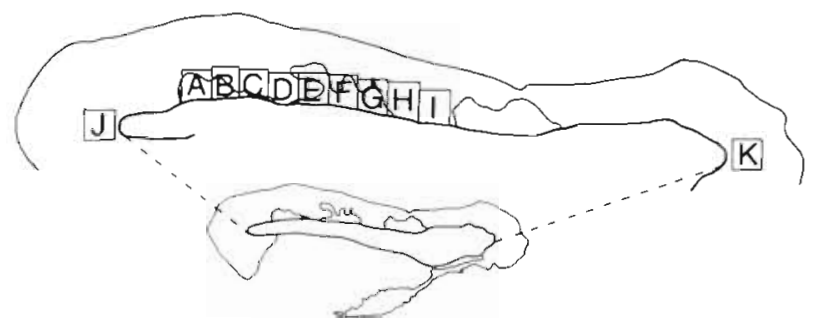

Fig. 3. Location of Quadrats A to K

ted from the holothuroid, and their contents removed. The sediment from each gut was sun-dried and sealed in plastic bags. Each fraction was subsequently oven- dried at $60^{\circ}$ for $48 \mathrm{~h}$, weighed, wet-sieved with a $0.05 \mathrm{~mm}$ sieve, dried and weighed once more. Afterwards, it was sieved over 8 Standard American Sieve Units $(0.106,0.210,0.421,0.595,0.841,1.180,2.000$, $3.150 \mathrm{~mm}$ ). Bottom sediments collected in the field were treated in the same way.

\section{RESULTS}

Six epibenthic species of holothuroids were found on the east reef flat of Laing Island: Actinopyga echinites (Jaeger), Actinopyga mauritiana (Quoy \& Gaimard), Bohadschia argus Jaeger, Holothuria atra Jaeger, Microthele nobilis (Selenka) and Synapta maculata (Chamisso \& Eysenhardt). Holothuria leucospilota (Brandt), a semi-cryptic species, was also present (Table 1).

Holothuria atra and $H$. leucospilota represented more than $90 \%$ of the total number of individuals (Table 2). The holothuroid fauna can be divided into 2 categories: those living in more or less sheltered areas (H. atra, $H$. leucospilota, Actinopyga echinites, Bohadschia argus, Synapta maculata) and those living in exposed areas (A. mauritiana, Microthele nobilis).

\section{Sheltered areas}

As wave energy diminishes with distance across the reef flat, most of the sheltered areas - viz. pools and the rubble reef flat - are situated near the beach. Hence, as Holothuria atra and $H$. leucospilota are characteristic of sheltered areas and are especially numerous, the highest densities of holothuroids occurred along the beach (Fig. 5, 6 \& 7) and decreased towards the reef edge.

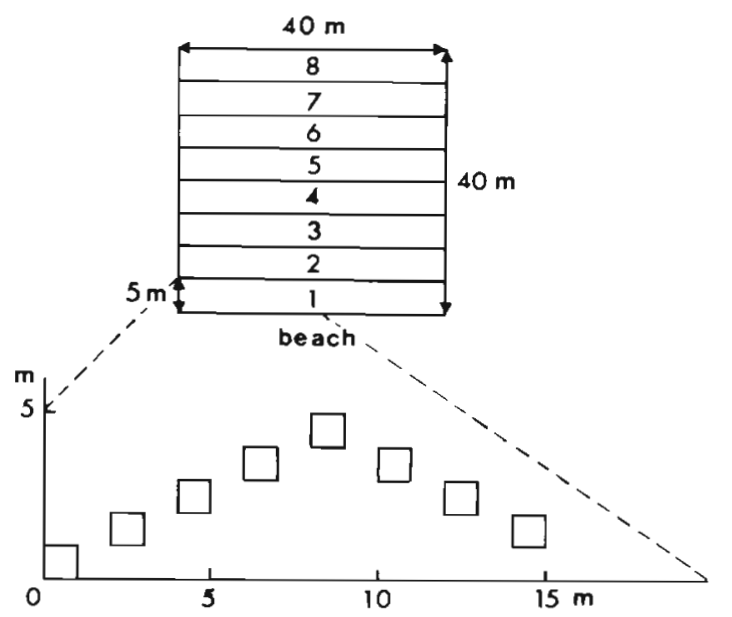

Fig. 4. Division of a $40 \times 40 \mathrm{~m}$ quadrat into 8 zones of $5 \times$ $40 \mathrm{~m}$, with the positions of the $1 \times 1 \mathrm{~m}$ frame in a zone 
Table 1. Presence (+) or absence (-) of holothuroids according to the type of bottom

\begin{tabular}{|c|c|c|c|c|}
\hline Species & On sand & $\begin{array}{l}\text { Under coral boulders } \\
\text { (partly) }\end{array}$ & $\begin{array}{l}\text { On rocks and/or } \\
\text { living corals }\end{array}$ & In seagrass bed \\
\hline Actinopyga echinites & + & - & - & + \\
\hline Actinopyga mauritiana & - & - & + & - \\
\hline Bohadschia argus & + & - & - & - \\
\hline Holothuria atra & + & - & + & + \\
\hline Holothuria leucospilota & - & + & - & - \\
\hline Microthele nobilis & - & - & + & - \\
\hline Synapta maculata & + & + & - & - \\
\hline
\end{tabular}

Table 2. Number of individuals observed in different quadrats of the reef flat, 1982 \& 1983 (see Fig. 2)

\begin{tabular}{|c|c|c|c|c|c|c|c|c|c|c|c|}
\hline \multirow[t]{2}{*}{ Species } & \multicolumn{11}{|c|}{ Quadrat } \\
\hline & A & B & $\mathrm{C}$ & $\mathrm{D}$ & $E$ & $\mathrm{~F}$ & $G$ & $\mathrm{H}$ & I & $\mathrm{J}$ & $\mathrm{K}$ \\
\hline Holothuria leucospilota & 1892 & 991 & 1886 & 850 & 474 & 310 & 90 & 112 & 130 & 4 & 0 \\
\hline Holothuria atra & 2336 & 1372 & 670 & 1150 & 1028 & 740 & 294 & 151 & 52 & 0 & 0 \\
\hline Actinopyga echinites & 119 & 76 & 72 & 39 & 21 & 44 & 9 & 2 & 4 & 0 & 0 \\
\hline Bohadschia argus & 4 & 34 & 0 & 0 & 0 & 1 & 0 & 0 & 0 & 0 & 0 \\
\hline Microthele nobilis & 6 & 0 & 0 & 0 & 3 & 3 & 1 & 0 & 2 & 0 & 0 \\
\hline Actinopyga mauritiana & 2 & 8 & 3 & 0 & 0 & 0 & 0 & 0 & 2 & 0 & 2 \\
\hline
\end{tabular}

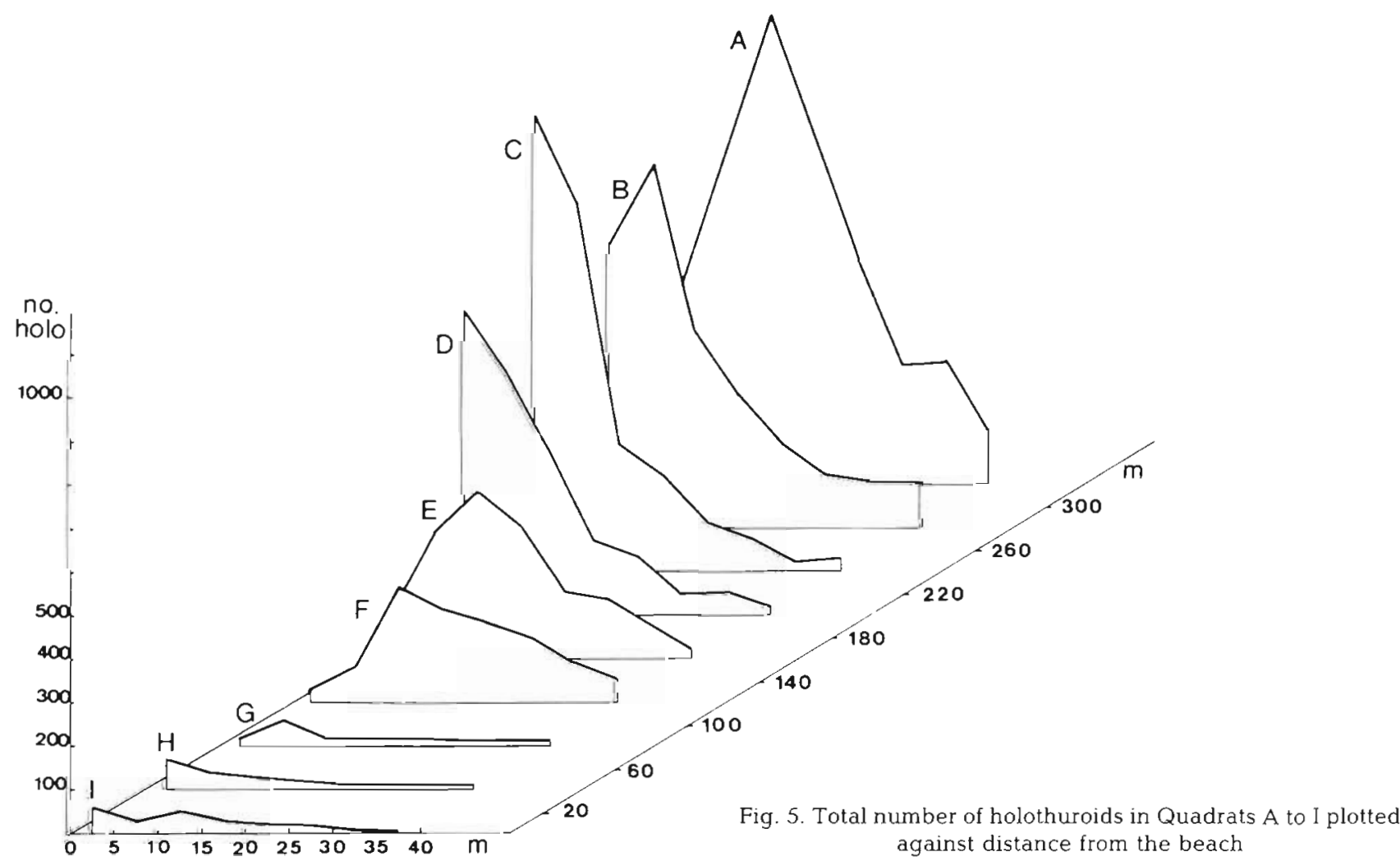




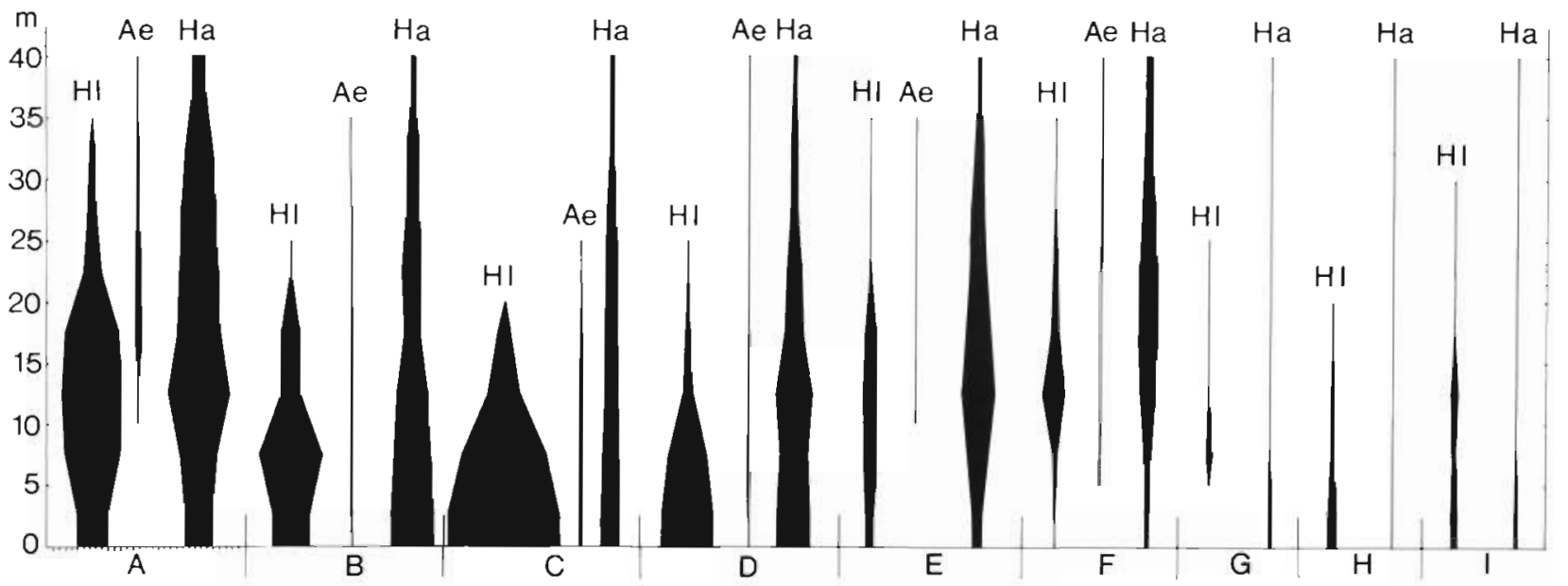

Fig. 6. Distribution of Holothuria leucospilota (H), Actinopyga echinites (Ae), and Holothuria atra (Ha) in Quadrats A to I. Each subdivision on the horizontal x-axis of Quadrat A represents 50 holothuroids. The same unit is used for the other quadrats

In only 3 quadrats $(A, F$ and $G$ ) did the maximum density shift from Zone 1 to Zone 2 or 3 (Fig. 6). There was a decrease in the total number of holothuroids from Quadrat A to I with a sudden drop at Quadrat $G_{\text {, }}$ all the species being affected similarly (Fig. 5). Only a few holothuroids occurred in the shallow part of Pool 3. The holothuroid fauna of Pool 4 was more or less the same as the one in Quadrat E. The length, weight and maximum densities of holothuroids sampled are given in Table 3.

\section{Holothuria atra}

Holothuria atra was the most widespread and most abundant species on the reef flat (Fig. 6). Its skin was almost always covered by a thin sand coat embedded in mucus, except for 2 characteristic dorsal rows of spots which remained naked (Fig. 1f). H. atra was the only species present throughout the area studied and was often found on dry areas during low tides. However, the population density was always higher in pools than on dry areas. Clusters of $H$. atra were never observed. Few species other than $H$. atra lived in the seagrass beds. The density of $H$. atra was not particu-

Table 3. Lengths, weights and maximum density of sampled individuals (1982)

\begin{tabular}{|lrrc|}
\hline Species & Length $(\mathrm{cm})$ & Weight (g) & $\begin{array}{c}\text { Max. density } \\
\left.\text { (ind } \mathrm{m}^{-2}\right\}\end{array}$ \\
\hline H. leucospilota & - & $91.32 \pm 26.40$ & 14 \\
H. atra & $13.2 \pm 3.6$ & $80.78 \pm 38.71$ & 6 \\
A. echinites & $16.6 \pm 2.9$ & $288.66 \pm 62.84$ & 0.215 \\
B. argus & $19.6 \pm 3.2$ & $519.30 \pm 68.60$ & 0.055 \\
\hline
\end{tabular}

Iarly higher there than elsewhere, but the absence of other holothuroids gave the impression of abundance. When ripple-marks were present (Zones A1, F1 and G1), the density of $H$. atra diminished but the species was never excluded.

Comparison of size-frequency distributions of ingested and bottom sediments indicates that Holothuria atra is a non-selective species as far as grain size is concerned (Fig. 8). It ingests sand continuously and the digestive tract is always full.

Populations from Zones A1 to A6 show a bimodal length frequency distribution (Fig. 9) in the first $10 \mathrm{~m}$ from the beach. Such a bimodal frequency of body length was also found in B1 to B6 and C1 \& 2). The average length of Holothuria atra was ca $13 \mathrm{~cm}$ with a maximum of $25 \mathrm{~cm}$. Slightly larger individuals occurred in well-sheltered areas.

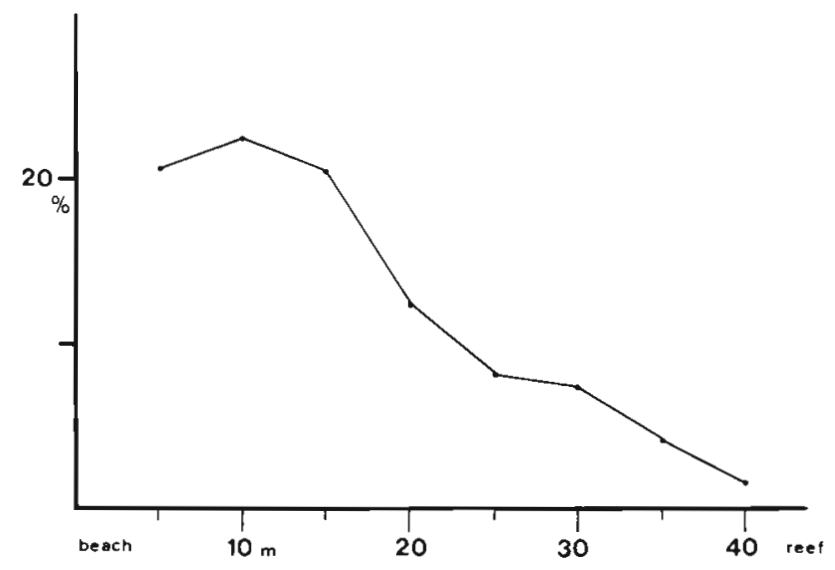

Fig. 7. Relation of distance from the beach to $\%$ of total observed holothuroids 

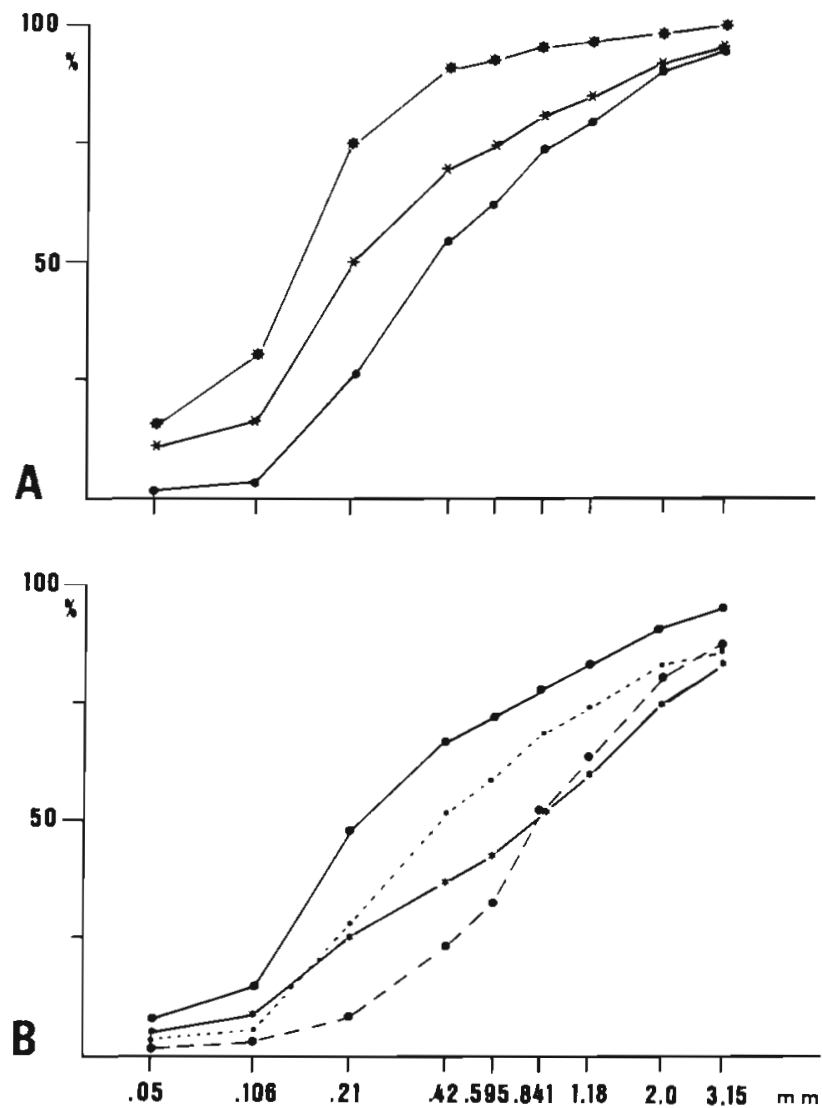

Fig. 8. Cumulative particle size distribution of gut sediment and bottom sediment. (A) Holothuria atra (•); Holothuria leucospilota (*); Actinopyga echinites (*). (B) Microthele nobilis $(\bullet-)$; Bohadschia argus $(* *)$ bottom sediment zones A1, $2(* \cdots *)$; bottom sediment zones A3, $4(\bullet--\bullet)$
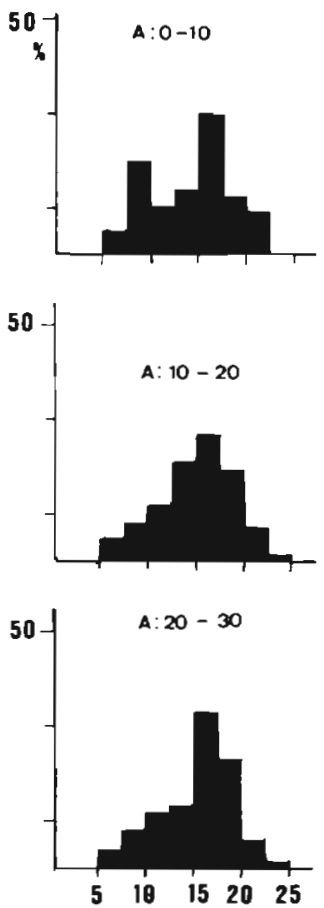
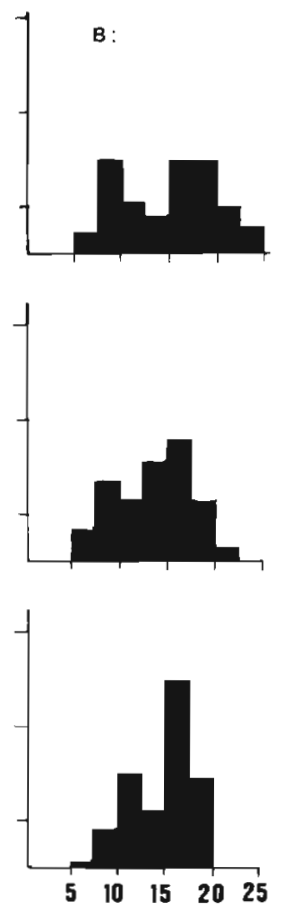
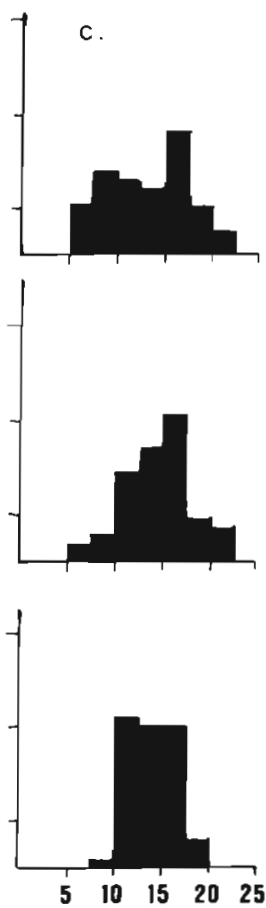

\section{Holothuria leucospilota}

Holothuria leucospilota had the highest population density of the holothuroid species on the east reef flat (Table 3). H. leucospilota has a naked and dark pigmented skin. Its posterior end was hidden and the highly mobile anterior end extended outward for feeding (Fig. 1e). The semi-cryptic habit of this species restricted its distribution to areas well provided with shelters. It demonstrated a patchy distribution, aggregating under stones, Tridacna shells and submerged tree trunks. $H$. leucospilota never occurred on dried surfaces, nor on living corals or on sites where water turbulence was high. $H$. leucospilota was also absent from the seagrass beds.

In the most seaward $10 \mathrm{~m}$ of Quadrats $\mathrm{A}$ to I, Holothuria leucospilota, if present, always had a density $\leqslant 0.05$ ind $\mathrm{m}^{-2}$. At sites where the bare coral slab came close to the beach (e.g. C5), H. leucospilota was absent, and was not found in zones with ripplemarks (F1, G1) unless shelters were present $(A 1,2)$. The maximum density was found in $\mathrm{C} 1 \& 2$. H. leucospilota ingested the finest fractions of the sediment (Fig. 8): particles $\leqslant 0.21 \mathrm{~mm}$ represented $50 \%$ of its gut sediment compared to $25 \%$ in the bottom sediment. During the day, the tentacles of $H$. leucospilota were active and the digestive tract was always full.
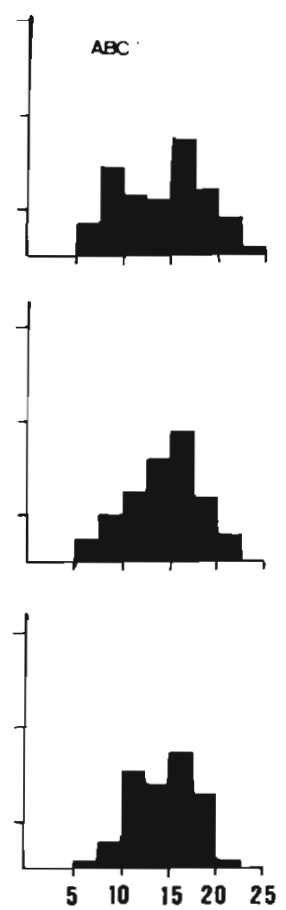

Fig. 9. Holothuria atra. Variation of body length $(\mathrm{cm})$ in Quadrats A, B, and $C$; measurements were taken on surfaces of $10 \times$ $40 \mathrm{~m}$, i.e. A $1,2(0$ to $10 \mathrm{~m})$. A. $3,4(10$ to $20 \mathrm{~m}), \mathrm{A}, 5,6(20$ to $30 \mathrm{~m}$ ). Last column represents sum of Quadrats $A, B$ and $C$ 


\section{Actinopyga echinites}

Atcinopyga echinites was found on permanently immersed sandy areas. When exposed, it becomes flattened and partially buried. Few individuals of this species were found in pools deeper than $15 \mathrm{~cm}$. A. echinites occurs in sandy areas provided with small stones but never hidden underneath. It does not occur in large sandy areas with turtle grass $(G 2,3)$ or with ripple-marks (A1, 2, E1, F1). The gut of A. echinites is free or nearly free of sand during the day and at low tide. Often a large fecal mound is found near the animal. Particles $\leqslant 0.21 \mathrm{~mm}$ represent $75 \%$ of its gut sediment (compared to $8 \%$ in the bottom sediment, Fig. 8). Individuals living in large pools have a greater length $(17.45 \pm 1.96 \mathrm{~cm})$ than those living in small pools (Quadrat D) $(15.44 \pm 2.38 \mathrm{~cm})$.

\section{Bohadschia argus and Synapta maculata}

Bohadschia argus was restricted to Pool 1 and particularly to Quadrat B. Specimens were small (19.6 \pm $3.2 \mathrm{~cm}$ ) in comparison with those of the lagoon, and always underwater. They cover themselves with rough sand and coral rubble. If the sand layer is deep enough, they burrow during the warmest hours of the day, leaving only the anus exposed.

Bohadschia argus was found on rough sandy sites. It was never observed on sand with ripple-marks, in shallow-water ( 1 to $3 \mathrm{~cm}$ depth), nor on muddy sediments. Its distribution was patchy. When foraging, $B$. argus was non-selective with regard to particles $\leqslant 0.106$ and $\geqslant 0.841 \mathrm{~mm}$ but selective for particles ranging from 0.21 to $0.6 \mathrm{~mm}$ (Fig. 8).

Synapta maculata was occasionally observed in Pools 1 and 4 . These animals are small (maximum $60 \mathrm{~cm}$ ) in comparison with those of the lagoon, and move quickly from one shelter to another. With an overcast sky they are more conspicuous.

\section{Holothuroid distribution over time}

As a rule the total number of holothuroids in each area was stable over time (Table 4). However, some variations occurred for each species. Between 1982 and 1985 a decrease of the Holothuria leucospilota population together with an increase of the $H$. atra population was observed.

During 1982, 1983 and 1985 the same patch of Actinopyga echinites was observed in the central part of F5, $6 \& 7$ where 10 to 20 specimens occurred per $200 \mathrm{~m}^{2}$. Around this patch there were no more than 1 or 2 A. echinites per $200 \mathrm{~m}^{2}$.
Table 4. Variation of density (ind $\mathrm{m}^{-2}$ ) of Holothuria atra and H. leucospilota between 1982 and 1985

\begin{tabular}{|lcccccc|}
\hline Species & \multicolumn{2}{c}{ Quadrat A } & \multicolumn{2}{c|}{ Quadrat F } & \multicolumn{2}{c|}{ Quadrat G } \\
& 1982 & 1985 & 1982 & 1985 & 1982 & 1985 \\
& & & & & & \\
\hline H. atra & 1.46 & 1.59 & 0.46 & 0.63 & 0.18 & 0.350 \\
H. leucospilota & 1.18 & 0.95 & 0.19 & 0.02 & 0.06 & 0.004 \\
Total & 2.64 & 2.54 & 0.65 & 0.65 & 0.24 & 0.354 \\
\hline
\end{tabular}

\section{Exposed areas}

Spur upper platforms, grooves, and irregular and scattered coral growths at the edge of the reef flat (Fig. $1 \mathrm{~d})$ are the most exposed areas. They correspond to the surf zone where the waves break, dissipating a maximum of energy. These areas supported only a few holothuroid species: those (especially Actinopyga mauritiana) able to crawl on living corals. The exposed areas of bare slabs of dead coral located at the north (Fig. 1b) and south points of the island almost completely lacked (Table 2) the species cited in Table 1.

\section{Actinopyga mauritiana and Microthele nobilis}

Actinopyga mauritiana and Microthele nobilis were not numerous on the reef flat of Laing Island. $A$. mauritiana appeared principally on the reef edge where living corals are found (Fig. 1d) or in pools with living corals. $M$. nobilis is found in sandy areas and its skin is sometimes covered by a thin sandy layer. $M$. nobilis forages selectively. Its cumulative curve of ingested sediment is nearly the same as that of $H$. leucospilota (Fig. 8). However, it must be more selective than $H$. leucospilota since it occurs on coarser sand.

\section{DISCUSSION}

The holothuroid fauna of the reef flat of Laing Island is similar to that observed on other Indo-Pacific coral reefs (Bonham \& Held 1963, Rowe \& Doty 1977, Roberts 1979, Sloan et al. 1979). However, the assemblage and the proportion of each species vary from one place to another (Table 5), seemingly dependent on local conditions. According to Yamanouchi (1939), Tyler \& Banner (1977), and Sloan \& Von Bodungen (1980), coastal perturbations are the most important factors regulating echinoderm distribution. Hydrodynamics influences 2 very important parameters, viz. sediment granulometry and larval dispersion.

On the Laing Island reef flat, the distribution of the main epibenthic and semi-cryptic holothuroids, i.e. Holothuria atra, $H$. leucospilota and Actinopyga 
Table 5. Holothuria atra, H. leucospilota and Actinopyga echinites. Occurence on Indo-Pacific coral reefs. -: not cited; + present; ++ : abundant ${ }_{i}++$ : very abundant

\begin{tabular}{|c|c|c|c|c|c|}
\hline Area & H. atra & H. leucospilota & A. echinites & $\begin{array}{l}\text { Other species of } \\
\text { aspidochirotes } \\
\text { observed in } \\
\text { the study area }\end{array}$ & Source \\
\hline Red Sea & + & - & - & 2 & Mergner 1979 \\
\hline Red Sea & - & + & - & 6 & Bertram 1936 \\
\hline Aldabra & + to ++ & + to $t+$ & + & 23 & Sloan et al. 1979 \\
\hline Aldabra & - & + & - & 2 & Sloan 1979 \\
\hline Mozambique & + to ++ & + & - & 9 & McNae \& Kalk 1962 \\
\hline Maldive, Lacadive & ++ & - & - & 1 & Gardiner 1904 \\
\hline Indonesia, Java & $+t+$ & +++ & + & 9 & Roberts 1979 \\
\hline Beacon Is. (Perth) & + & - & ++ & 5 & Roberts \& Bryce 1982 \\
\hline Palau Is. & +++ & - & - & 7 & Yamanouchi 1939 \\
\hline Guam & + & ++ & + & 17 & Rowe \& Doty 1977 \\
\hline Papua New Guinea & +++ & +++ & + & 5 & Present study \\
\hline Papua New Guinea & $+t$ & - & - & 13 & Brouns \& Heijs 1985 \\
\hline New Caledonia & ++ & - & + to +++ & 15 & Intes \& Menou 1979 \\
\hline New Hebrides & +++ & + & - & 2 & Baker 1929 \\
\hline Marshall Is. & +++ & ++ & - & 3 & Bonham \& Held 1963 \\
\hline Marshall Is. & +++ & + & - & 2 & Bakus 1968 \\
\hline Marshall Is. & +++ & + to ++ & - & 4 & Lawrence 1980 \\
\hline Line Is. & + & + & - & 9 & Townsley \& Townsley 1972 \\
\hline Tuamotou Archip. & +++ & - & - & 0 & Salvat 1975 \\
\hline
\end{tabular}

echinites, was also mainly related to the intensity of coastal wave action. The southern and particularly the northern reef flat are the more turbulent areas and are free of any shelter. Consequently the above mentioned species were virtually absent.

From Quadrats A to I there was a decrease in the total number of holothuroids. This decrease could partly be associated with the narrowing of the reef flat, and consequent reduced protection against wave action. Moreover, going from north to south up to Pool 3 the reef flat becomes progressively lower, especially to the seaward of Pools 2 and 3 . As the width of the reef flat changes in a regular way, the holothuroid population should change similarly. However, between Quadrats $F$ and $G$ there was an abrupt decrease in the total number of holothuroids. We have no certain explanation for this phenomenon. Possibly the lowering of the reef flat is important. Done (1983) suggests that an elevational difference of only a few centimetres, or a lateral distance of just a few meters, may be accompanied by major differences in substrate or hydrodynamic regime and marked associated changes in species composition. We can also suggest that the appearance between Quadrats F and G of nonoxygenated sand could be related to this sudden change. According to Yamanouchi (1939), anaerobic sediments rich in hydrogen sulfide are unfavourable to holothuroids. These sediments around Laing Island are also poor in meiofauna such as copepods and ostracods (Wouters pers. comm.).
Holothuroids were absent or nearly absent from areas with ripple-marks (e.g. along the beach in Quadrats $F$ and G). Such areas are unfavourable to holothuroids because they correspond to places where strong water movement (high flow velocity, wave action) occurs and where the sediment contains few bacteria (Sanders et al. 1962) and little organic matter (Massin 1978). Nevertheless, holothuroids were sometimes observed on areas with ripple-marks (e.g. Quadrat $A)$. This seems to be associated with the presence of numerous shelters.

As the highest densities of holothuroids always corresponded to large pools or to areas with many small pools and coral boulders (e.g. Quadrat C), the presence of water must be very important for reef flat holothuroids. This seems self-evident for animals with soft bodies exposed to full sunlight. However, if water on the reef flat at low tide is a condition promoting the presence of holothuroids, it is not a sufficient one, as some large pools are free or nearly free of holothuroids. The quality of water and the kind of bottom present are thus determining factors. High water temperature does not seem to be a factor limiting the dispersion of holothuroids (especially Holothuria atra). Apparently some of them tolerate temperatures above $38^{\circ} \mathrm{C}$ very well for a few hours.

The 3 most abundant species of the Laing Island reef flat had their maximum densities more or less in the same areas. This means that there is no competitive exclusion between these species with regard to the 
macrohabitat. Of the holothuroid species studied, Holothuria atra was the most abundant and widespread. It is also the most widespread throughout the Inda-Pacific Ocean. This wide distribution is the result. of the high tolerance of $H$. atra to many ecological parameters. However, it is not necessarily the most abundant species (Sloan et al. 1979). The observed distribution of $H$. atra is very similar to the one observed by Taylor \& Lewis (1970) in the marine grass beds of the reef flat of Mahé (Seychelles). In both areas studied the bulk of the population lay near the beach and decreased similarly out towards the reef edge.

The bimodal length frequency distribution of Holothuria atra is not related to any of the environmental factors measured. It could be ascribed to the asexual reproduction by transverse fission exhibited by $H$. atra. However, Bonham \& Held (1963) and Ebert (1978) did not find bimodality in the length frequency distribution of $H$. atra although it clearly exhibits transverse fission.

Holothuria atra and Actinopygia echinites may, according to the circumstances, occupy different ecological niches. For instance, we never observed $A$ echinites on dried surfaces at low tide whereas at Nouméa (New Caledonia) this species survives desiccation very well (Intes \& Menou 1979). This opportunistic behaviour has been observed in other species like Isostichopus badionotus of the Bermuda Platform (Sloan \& Von Bodungen 1980). The semi-cryptic way of life of $H$. leucospilota, on the other hand, occurs throughout the Indo-Pacific Ocean (Baker 1929, Bonham \& Held 1963, Rowe \& Doty 1977, Sloan 1979, Sloan et al. 1979, Lawrence 1980) whatever the cooccuring species. This constant ecological need restricts the distribution of $H$. leucospilota to wellsheltered areas, and explains its absence from the sparse seagrass beds at Laing Island which are free of boulders and stones. If seagrass beds are very dense, H. leucospilota is also absent (Brouns \& Heijs 1985). According to the description of the area studied by Brouns \& Heijs, boulders and stones were lacking in the seagrass beds

With regard to selectivity of ingested food, it is very difficult to compare our results with those of Roberts (1979) because he gave no indication of the particlesize distribution of the bottom sediment. Nevertheless as Holothuria atra is non-selective (Trefz 1958, Lawrence 1980, Roberts \& Bryce 1982, present study) it is reasonable to conclude that the cumulative particle size distribution of its gut contents was similar to that of the bottom sediment. Since the cumulative curves of our bottom sediment and of the ingested sediment of $H$. atra given by Roberts (1979) are identical, the bottom sediment should be very similar in both areas studied. On this basis, Actinopyga echinites seems to be much more selective when ingesting sediment at Laing Island (75\% of the gut sediment was $\leqslant 0.21 \mathrm{~mm}$ diameter) than in Jakarta Bay, Indonesia (Roberts 1979; ca $20 \%$ of the gut sediment was $\leqslant 0.25 \mathrm{~mm}$ diameter). This variability in the ingested sediment for a species - also noted by Levin (1979) - raises questions about the hypothesis of Roberts (1979) on the relation between the selectivity and structure of the tentacles. The anatomy of holothuroid tentacles (Roberts 1979, Bouland et al. 1982, Hammond 1982, Roberts \& Bryce 1982) and the present results strongly suggest that the structure of peltate tentacles belonging to Holothuridae are not related to sorting of the sediment available.

While chemical selectivity seems to be the rule for many littoral and abyssal holothuroids (Massin 1982), physical selectivity is disputed. According to Bertram (1936), Yamanouchi (1939), Yingst (1976), Sloan \& Von Bodungen (1980), Bouland et al. (1982), Hammond (1982), Levin (1982) and Massin (1982) holothuroids are not physically selective. This implies that grain size selectivity is not a significant mechanism for resource partitioning between coexisting species of tropical holothuroids. On the other hand, Hauksson (1979), Roberts (1979), Sloan \& Von Bodungen (1980), Roberts \& Bryce (1982), and the present study do show evidence of physical selectivity. However the results of Roberts (1979) are difficult to interpret because he never gave the composition of the bottom sediment. And, as shown by Levin (1979), Lawrence (1980), and Sloan \& Von Bodungen (1980), differences in the gut sediment sometimes reflect only a difference in the bottom sediment. The contradictory results on the feeding selectivity for holothuroid family (e.g. Stichopodidae, Sloan \& Von Bodungen 1980) or for a holothuroid species (e.g. Actinopyga echinites or Holothuria leucospilota, as mentioned above) may be only the result of the opportunistic behaviour of many holothuroid species.

The other species studied at Laing Island were not numerous enough to draw any conclusions. Nevertheless we note that body size is more or less the same for all the species whose ingested sediment had been studied, and that there is no apparent relation between body size and particle size classes of the gut sediment, contrary to the observation of Sloan (1979).

Although sieving is not the best method of estimating the sediment complexity (Whitlach 1981) our results are in agreement with the general statement that particle size selection in deposit feeders is an important mechanism for allowing ecologically similar species to coexist. It seems that selectivity depends little or not at all on the tentacle structure; also, environmental factors and ecological pressure of cooccurring species influence the grain size frequency 
distribution of the ingested sediment. According to these points, contradictory results may be only an indication of different conditions as well as opportunistic feeding potentiality of the species studied. More information and principally more in situ observations are necessary to resolve the present contradictions.

Acknowledgements. We thank Dr. J. M. Lawrence and Dr. M. Jangoux for critically reading the manuscript; Dr. E. Coppejans for identification of the seagrass; Dr. J. Boullon for facilities at Laing Island Biological Station; Mr. S. Luxford and Mr. A. Lievrouw for their help during field work at Laing Island; the Belgian Fund for Basic Research (grant No. 2.9005.82) and the King Leopold III Fund for their financial support.

\section{LITERATURE CITED}

Baker, J. R. (1929). On the zonation of some coral reef Holothuria. J. Ecol. 17: 141-143

Bakus, G. J. (1968). Defense mechanisms and ecology of some tropical holothurians. Mar. Biol. 2: 23-32

Bakus, G. J. (1973). The biology and ecology of tropical holothurians. In: Jones, O. A., Endean, R. (ed.) Biology and geology of coral reefs, Vol. II. Academic press, New York, p. $325-367$

Battistini, R., Bourrouilh, F., Chevalier, J.-P., Coudray, J., Denizot, M., Faure, G., Fischer, J.-C., Guilcher, A., Harmelin-Vivien, M., Jaubert, J., Laborel, J., Montaggioni, L., Masse, J.-P., Mauge, L., Peyrot-Clausade, M., Pichon, M., Plante, R., Plaziat, J.-C., Plessis, Y. B., Richard, G., Salvat, B., Thomassin, B. A., Vasseur, P., Weydert, P. (1975). Eléments de terminologie récifale indopacifique. Tethys 7 (1): 1-111

Bertram, G. C. L. (1936). Some aspects of the breakdown of coral at Ghardaqa, Red Sea. Proc. Zool. Soc. Lond.: 1011-1026

Bonham, K., Held, E. E. (1963). Ecological observations on the sea cucumbers Holothuria atra and $H$. leucospilota at Rongelap Atoll, Marshall Islands. Pacif. Sci. 17: 305-314

Bouland, C., Massin, C., Jangoux, M. (1982). The fine structure of the buccal tentacles of Holothuria forskali (Echinodermata, Holothuroidea). Zoomorphology 101: 133-149

Brouns, J. W. M., Heijs, F. M. L. (1985). Tropical seagrass ecosystems in Papua New Guinea. A general account of the environment, marine flora and fauna. Proc. K. ned. Akad. Wet, Ser. C, 88 (2): 145-182

Claereboudt, M., Massin, C., Boulion, J. (in press). General description of Laing Island and its surrounding reef. Indo Malayan Zool.

Done, T. J. (1983). Coral zonation: its nature and significance In: Barnes, D. J. (ed.) Perspective on coral reefs. Australian Inst. Mar. Sci. Contribution 200. B. Clouston, Manuka, p $107-147$

Ebert, T. A. (1978). Growth and size of the tropical sea cucumber Holothuria (Halodeima) atra Jaeger at Enewetak Atoll, Marshall Islands. Pacif. Sci. 32 (2) 183-191

Gardiner, J. S. (1904). The Maldive and Laccadive Groups, with notes on other coral formations in the Indian Ocean Fauna u. Geogr. Mald. Laccad. Archip. 1 (3): 313-346

Hammond, L. S. (1982). Analysis of grain-size selection by deposit-feeding holothurians and echinoids (Echinoder- mata) from a shallow reef lagoon, Discovery Bay, Jamaica. Mar. Ecol. Prog. Ser. 8: 25-36

Hauksson, E. (1979). Feeding biology of Stichopus tremulus, a deposit feeding holothurian. Sarsia 64: 155-160

Intes, A., Menou, J. L. (1979). Quelques holothuries (Echinodermata) des environs de Nouméa et leur repartition. O.R.S.T.O.M. Rapp. Sci. Tech. 3: 1-13

Kohn, A. J. (1971). Diversity, utilization of resources, and adaptive radiation in the shallow-water marine invertebrates of tropical ocean islands. Limnol. Oceanogr. 16: $332-348$

Lawrence, J. M. (1980). Numbers and biomass of the common holothuroids on the windward reef flat at Enewetak Atoll, Marshall Islands. In: Jangoux, M. (ed.) Echinoderms present and past. Balkema, Rotterdam, p. 201-204

Levin, V. S. (1979). Composition of food particles of Aspidochirote holothurians of the upper sublittoral of the Indo-West Pacific. Biol. Morja Vladiv. 6: 20-27

Levin, V. S. (1982). Trepang (Japanese sea cucumber). Far Eastern Book Edition, Vladivostok

MacNae, W., Kalk, M. (1962). The fauna and flora of a sand flat at Inhaca Island, Moçambique. J. Anim. Ecol. 31: 93-128

Massin, C. (1978). Étude de nutrition chez les holothuries aspidochirotes (Échinodermes). Comportement alimentaire, structure et fonction de l'appareil digestif. Doctoral thesis, Université Libre de Bruxelles

Massin, C. (1982). Food and feeding mechanisms: Holothuroidea. In: Jangoux, M., Lawrence, J. (ed.) Echinoderm nutrition. Balkema, Rotterdam, p. 43-55

Mergner, H. (1979). Quantitative ökologische Analyse eines Rifflagunenareals bei Aqaba (Golf von Aqaba, Rotes Meer). Helgoländer Meeresunters. 32: 476-507

Roberts, D. (1979). Deposit feeding mechanisms and resource partitioning in tropical holothurians. J. exp. mar. Biol. Ecol. 31: 43-56

Roberts, D., Bryce, C. (1982). Further observations on tentacular feeding mechanisms in holothurians. J. exp. mar. Biol Ecol. 59: 151-163

Rowe, F. W. E., Doty, J. E. (1977). The shallow-water holothurians of Guam. Micronesica 13: 217-250

Salvat, B. (1975). Répartition et abondance d'Halodeima atra - échinoderme, holothuride - dans les lagons et les récifs coralliens de Polynésie française. 13ème Congrès Scient. Pacif. C.R. 1 Récifs Coralliens, Pacific Science Association, Vancouver, p. 126

Sanders, H. L., Goudsmit, E. M., Mills, E. L., Hampson, G. E. (1962). A study of the intertidal fauna of Barnstable Harbor, Massachusetts. Limnol. Oceanogr. 7: 63-79

Sloan, N. A. (1979). Microhabitat and resource utilization in cryptic rocky intertidal echinoderms at Aldabra Atoll, Seychelles. Mar. Biol. 54: 269-279

Sloan, N. A., Bodungen, B. von (1980). Distribution and feeding of the sea cucumber, Isostichopus badionotus in relation to shelter and sediment criteria of the Bermuda Platform. Mar. Ecol. Prog. Ser. 2: 257-264

Sloan, N. A., Clark, A. M., Taylor, J. D. (1979). The echinoderms of Aldabra and their habitats. Bull. Br. Mus. nat. Hist. Zool. Ser. 37 (2): 81-128

Taylor, J. D., Lewis, M. S. (1970). The fauna, flora and sediments of the marine grass beds of Mahé, Seychelles. J. nat. Hist. 4: 199-219

Townsley, S. L., Townsley, M. P. (1972). A preliminary investigation of the biology and ecology of the holothurians at Fanning Island. Rep. Fanning Isl. Exp. Hawaii Inst. Geophys. Univ. Hawaii, Report HIG73, p. 173-183

Trefz, S. M. (1958). The physiology of digestion of Holothuria 
atra Jaeger with special reference to its role in the ecology of coral reefs. Ph. D. dissertation, Univ. Hawaii

Tyler, P. A., Banner, F. T. (1977). The effect of coastal hydrodynamics on the echinoderm distribution in the sublittoral of Oxwich Bay, Bristol Channel. Estuar. coast. mar. Sci. 50: 293-308

Whitlach, R. B. (1981). Animal-sediment relationships in intertidal marine benthic habitats: some determinants of deposit-feeding species diversity. J. exp. mar. Biol. Ecol. 53: $31-45$

Yamanouchi, T. (1939). Ecological and physiological studies on the holothurians in the coral reef of Palao Islands. Palao trop. biol. Stn Stud. 4: 603-636

Yingst, J. Y. (1976). The utilization of organic matter in shallow marine sediments by an epibenthic deposit-feeding holothurian. J. exp. mar. Biol. Ecol. 23: 55-69

This article was submitted to the editor; it was accepted for printing on March 24, 1986 